\title{
A stability-indicating HPLC-PDA method for the determination of ferulic acid in chitosan-coated poly(lactide-co-glycolide) nanoparticles
}

\author{
Isabela Angeli de Lima, Najeh Maissar Khalil, Rubiana Mara Mainardes*
}

Department of Pharmacy, Laboratory of Pharmaceutical Nanotechnology, Universidade Estadual do Centro-Oestel

UNICENTRO, Guarapuava, PR, Brazil

\begin{abstract}
The development and validation of a simple and efficient method for the quantification of ferulic acid in poly (D,L-lactide-co-glycolide) (PLGA) nanoparticles coated with chitosan (CS) by reverse phase high performance liquid chromatography coupled to photodiode array detection was described. For the chromatographic analysis, a reverse phase C-18 column was used, mobile phase consisting of acetonitrile and $0.5 \%$ acetic acid $(37: 63, \mathrm{v} / \mathrm{v})$, isocratically eluted at a flow rate of $1 \mathrm{~mL} / \mathrm{min}$. Drug determination was performed at $320 \mathrm{~nm}$. The method was validated in terms of the selectivity, linearity, precision, accuracy, robustness, limits of detection and quantification. The method was linear in the range of 10 to $100 \mu \mathrm{g} / \mathrm{mL}(\mathrm{r}=0.999)$ and presented limit of detection and quantification of $102 \mathrm{ng} / \mathrm{mL}$ and $310 \mathrm{ng} / \mathrm{mL}$, respectively. The method was precise (intra and inter-day) based on relative standard deviation values (less than $3.20 \%$ ). The recovery was between 101.06 and $102.10 \%$. Robustness was demonstrated considering change in mobile phase proportion. Specificity assay showed no interference from the components of nanoparticles or from the degradation products derived from acidic and oxidative conditions. The proposed method was suitable to be applied in determining the encapsulation efficiency of ferulic acid in PLGA-CS nanoparticles and can be employed as stability indicating one.
\end{abstract}

Uniterms: Nanoparticles. Ferulic acid/encapsulation efficiency. Ferulic acid/quantification. Stability. High performance liquid chromatography/validation. PLGA-poly(lactide-co-glycolide)/nanoparticles. Chitosan.

\section{INTRODUCTION}

Trans ferulic acid (FA) [(E) -3- (4-hydroxy3 -methoxy-phenyl) propyl-2-enoic acid] is a hydroxycinnamic acid and polyphenolic present in a variety of cereals, fruits and vegetables, such as rice, coffee, wheat, apple, peanut (Wu et al., 2014), artichoke, eggplant and corn meal (Trombino et al., 2013). It presents bonded to the cell wall of plants, usually linked to proteins and polysaccharides, thus, it is rarely found in its free form (Aceituno-Medina et al., 2015). Studies indicate the potential use of FA as anti-inflammatory, antithrombotic, antitumor, antiviral, immunoprotective, antibacterial, protector against ultraviolet rays and

\footnotetext{
*Correspondence: R. M. Mainardes. Departamento de Farmácia. Laboratório de Nanotecnologia Farmacêutica. Universidade Estadual do Centro-Oeste UNICENTRO. Rua Simeão Camargo Varela de Sá, 03 - 85040-080 - Guarapuava

- PR, Brasil. E-mail: rubianamainardes@hotmail.com
}

especially as antioxidant (Kim et al., 2013; Lima, Duarte, Esteves, 2013; Yang, Song, 2015). However, FA has some limitations that affect its therapeutic efficacy when orally administered. It presents broad hepatic metabolism (Trombino et al., 2013), reduced half-life, low aqueous solubility (Zhou et al., 2015), reduced ability to penetrate biological membranes (Trombino et al., 2013; Yang, Song, 2015), instability against oxidation and low cellular uptake (Kim et al., 2013). An alternative to overcome physicochemical, biopharmaceutical and pharmacokinetics drawbacks of drugs administered by oral route is the use of nanocarrier systems, such as the polymeric nanoparticles.

Polymeric nanoparticles improve drug absorption and bioavailability, promote prolonged and/or specific drug release, improving the drug uptake by target cells, and thus, decreasing its toxicity (De Jong, Borm, 2008). The appropriate characterization of nanoparticles is an 
important step to ensure the therapeutic efficacy. The amount of drug-loaded in nanoparticles, drug stability and drug delivery profile must be adequately determined, and thus, suitable and validated analytical methods are necessary (Das Neves et al., 2010).

FA has been quantified by many analytical methods, such as high-performance liquid chromatography (HPLC) coupled with photodiode array wavelength detector (PDA) or UV-Vis detector (Anselmi et al., 2006; Craparo et al., 2009; Kareparamban et al., 2013; Li et al., 2007; Li et al., 2004; Li, Bi, 2003; Lu et al., 2005; Nadal et al., 2015; Picone et al., 2009; Qi et al., 2007; Wang et al., 2011), liquid chromatography tandem mass spectrometry (Guy et al., 2009; Wang et al., 2013; Zhang et al., 2009), UV-Vis spectroscopy (Lima et al., 2013; Merlin et al., 2012), thin layer chromatography (Mabinya, Mafunga, Brand, 2006), high-performance thin layer chromatography (Hingse, Digole, Annapure, 2014; Srivastava, Singh, Singh Rawat, 2012), gas chromatography (Olthof et al., 2003), chemiluminescence (Shen et al., 2013), capillary electrophoresis (Lima, Duarte, Esteves, 2007), micellar electrokinetic chromatography (Guo et al., 2003), electrochemical analysis (Vilian, Chen, 2014) and paper-based platforms (Tee-Ngam et al., 2013). However, HPLC is considered the most reliable and popular methodology for investigating phenolic acids (Barberousse et al., 2008).

Moreover, most of these studies are about quantification of FA coupled with other phenolic compounds or other components extracted from plants (Andreasen et al., 2000; Guo et al., 2003; Sen et al., 1991; Srivastava, Singh, Singh Rawat, 2012; Vichapong et al., 2010; Waldron et al., 1996), or about the quantification of FA in rat plasma (Li, Bi, 2003; Qi et al., 2007; Rondini et al., 2004). There are few studies about the analysis of FA in products with pharmaceutical potential and among these are even rarer those with a documented validation study (Nadal et al., 2015). Some studies show the determination of FA in lipid nanoparticles (Bondi et al., 2009; Carbone et al., 2014; Trombino et al., 2013), metallic (Vilian, Chen, 2014), magnetic (Saikia et al., 2013) and in poly(lactide-co-glycolide) (PLGA) nanoparticles by UV spectrophotometer (Merlin et al., 2012).

Thus, aiming the adequate characterization of the FA-loaded nanoparticles and to supply the lack of suitable validated methods for quantification of FA in pharmaceutical dosages, in this work it was developed and validated a simple and fast analytical methodology by reverse phase HPLC-PDA to quantify FA in PLGA nanoparticles coated with chitosan (CS).

\section{MATERIAL AND METHODS}

\section{Chemical and reagents}

CS (medium molecular weight, 75-85\% deacetylated), FA (99\% purity), PLGA (65:35, 40000$75000 \mathrm{Da}$ ), and polyvinyl alcohol (PVA, 31KDa, 88\% hydrolyzed) were purchased from Sigma Aldrich (St. Louis, MO, USA). HPLC grade acetonitrile and ethanol were obtained from LiChrosolv-Merck (Darmstadt, HE, Germany). Acetic acid was purchased from Vetec Química Fina (Duque de Caxias, RJ, Brazil), dichloromethane from Fmaia (Belo Horizonte, MG, Brazil), hydrochloric acid from Dinâmica (Diadema, SP, Brazil) and hydrogen peroxide and sodium hidroxyde were obtained from Biotec (Pinhais, PR, Brazil). The water used was purified with a Milli-Q Gradient ${ }^{\circledR}$ (Millipore ${ }^{\circledR}$, Darmstadt, HE, Germany), with 18.2 conductivity $\mathrm{M} \Omega / \mathrm{cm}$.

\section{Chromatographic conditions}

For the development and validation of the methodology, it was used a HPLC Waters 2695 Alliance (Waters ${ }^{\circledR}$, Milford, MA, USA) combined with a PDA Waters 2998 (Waters $^{\circledR}$, Milford, MA, USA). HPLC system was equipped with a column compartment with temperature control, on line degasser, quaternary pump, auto sampler and auto injector. The analyses were realized using a reverse phase $\mathrm{C} 18$ chromatograph column (Vertical ${ }^{\circledR}$, Bangkok, Thailand) with $5 \mu \mathrm{m}$ particle size, $4.6 \mathrm{~mm}$ internal diameter and $250 \mathrm{~mm}$ length.

To ensure optimal chromatographic conditions, variations in the proportion of components of the mobile phase, the sample dilution solvent, the flow rate and in the injection volume were performed. The most appropriate chromatographic conditions were selected from the chromatographic peak characteristics and subsequently validated. The mobile phase was composed of acetonitrile and $0.5 \%$ acetic acid $(37: 63, \mathrm{v} / \mathrm{v})$, eluted at a flow rate of $1.0 \mathrm{~mL} / \mathrm{min}$ in isocratic mode. The injection volume was $10 \mu \mathrm{L}$ and the analyses were performed at $320 \mathrm{~nm}$ at $25.0 \pm 1.0^{\circ} \mathrm{C}$.

\section{Preparation of standard and sample solutions}

A standard stock solution of FA $(1 \mathrm{mg} / \mathrm{mL})$ was prepared in acetonitrile. After, subsequent dilutions in acetonitrile were performed in order to obtain six standard solutions $(10 ; 30 ; 50 ; 60 ; 80$ and $100 \mu \mathrm{g} / \mathrm{mL})$. FA samples corresponded to supernatant originated after ultracentrifugation of nanoparticles containing FA, as 
described further. Prior to injection, standard and sample solutions were filtered through $0.22 \mu \mathrm{m}$ filter pore size.

\section{System suitability}

The system suitability was carried out based on the analysis of five replicates of FA standard solution (50 $\mu \mathrm{g} / \mathrm{mL})$. The system performance was evaluated by the following parameters: number of theoretical plates $(\mathrm{N})$, tailing factor $(\mathrm{T})$ and retention factor $(\mathrm{k})$.

\section{Method validation}

Validation was conducted following the guide's recommendations International Conference on Harmonization (ICH) $(\mathrm{ICH}, 2005)$ and $\mathrm{AOAC}$ International Standard (AOAC) (AOAC, 2016). The parameters used for this validation were linearity, range, accuracy, precision, limit of detection and limit of quantification, specificity and robustness.

\section{Specificity}

The specificity was evaluated by comparing the chromatograms obtained for the supernatant of blank nanoparticles (without FA) and chitosan solution with chromatograms of samples containing FA and FA standard solution.

\section{Linearity and range}

Linearity of the method was evaluated from the construction of three independent calibration curves (peak area versus drug concentration) using six FA standard solutions $(10 ; 30 ; 50 ; 60 ; 80$ and $100 \mu \mathrm{g} / \mathrm{mL})$. The linearity was evaluated by the linear regression and the correlation coefficient ( $r$ ), and can be considered satisfactory if $(r) \geq 0.99$. The statistical analysis to evaluate the linearity and deviation from linearity was performed by analysis of variance (ANOVA).

\section{Limit of detection (LOD) and limit of quantification (LOQ)}

The LOD and LOQ were obtained based upon the slope $(\mathrm{S})$ of the calibration curve and least standard deviation obtained from the response $(\sigma)$, according to Eq. 1 and Eq. 2 (ICH, 2005) from a specific calibration curve constructed by analysis in triplicate of five FA standard solutions with concentrations of $0.5 ; 2 ; 5 ; 7$ and $10 \mu \mathrm{g} / \mathrm{mL}$ :

$$
L O D=3.3 \times \frac{\alpha}{S} \quad \text { Equation } 1
$$

$$
L O Q=10 \times \frac{\alpha}{S} \quad \text { Equation } 2
$$

Precision: repeatability and intermediate precision

The repeatability of the method was evaluated by analysis of FA sample solution (supernatant of FA-loaded nanoparticles) in concentrations of 10; 50 and $100 \mu \mathrm{g} /$ $\mathrm{mL}$, and for each concentration, five solutions were injected on the same day, in a short period of time. To the intermediate precision, samples were analyzed in the same way, however repeated on three different days. The precision was expressed as mean \pm standard deviation (SD) and relative standard deviation (RSD).

\section{Accuracy}

The accuracy was verified by spiking blank nanoparticles with known concentrations of FA solution to obtain final concentrations of 10,50 and $100 \mu \mathrm{g} / \mathrm{mL}$, analyzed in quintuplicate. It was determined the RSD and the percentage of recovery (Eq. 3).

Recovery $=100 \times \frac{\text { average measured concentration }}{\text { theorical concentration }} \quad$ Equation 3

\section{Robustness}

Robustness was determined by changes in the ratio of mobile phase (acetonitrile:0.5\% acetic acid - 35:65 and $39: 61 \mathrm{v} / \mathrm{v})$ and in the flow rate $(0.95$ and $1.05 \mathrm{~mL} /$ $\mathrm{min})$. There were used FA solutions with concentrations of 10,50 and $100 \mu \mathrm{g} / \mathrm{mL}$. The percentage of recovery and the RSD were determined, and to verify the presence of significant difference, analysis of variance (ANOVA) with Tukey's multiple comparisons test were performed $(\mathrm{p}<0.05)$.

\section{Forced Degradation Studies}

For evaluation of drug stability and selectivity with respect to degradation products, FA standard solutions (50 $\mu \mathrm{g} / \mathrm{mL}$ ) were subjected to forced degradation. Solutions were exposed during $24 \mathrm{~h}$ to basic hydrolysis $(1 \mathrm{~mol} / \mathrm{L}$ $\mathrm{NaOH}-\mathrm{pH}: 13.50)$, acid hydrolysis $(1 \mathrm{~mol} / \mathrm{L} \mathrm{HCl}-\mathrm{pH}$ $0.39)$, oxidative reaction $\left(3 \% \mathrm{H}_{2} \mathrm{O}_{2}\right)$, visible light, and temperature of $-20^{\circ} \mathrm{C}$.

\section{Method applicability}

Nanoparticles containing FA were obtained by the single-emulsion solvent evaporation method. Briefly, an organic solution was prepared by the dissolution of PLGA and FA in ethanol $(200 \mu \mathrm{L})$ and dichloromethane $(1.8 \mathrm{~mL})$. The aqueous phase consisted of $10 \mathrm{~mL}$ of chitosan solution $(0.16 \% \mathrm{w} / \mathrm{v})$ and polyvinyl alcohol (PVA) $(1 \%, \mathrm{w} / \mathrm{v})$, both 
dissolved in $2 \%$ acetic acid (v/v). The organic phase was added to the aqueous phase and sonicated for $5 \mathrm{~min}$ using a probe sonicator $\left(\mathrm{QR} 1000, \mathrm{Eco}_{-}\right.$Sonic $^{\circledR}$, Indaiatuba, SP, Brazil) to produce an oil-in-water emulsion. Next, the organic solvent was evaporated under vacum for $15 \mathrm{~min}$ at $37^{\circ} \mathrm{C}$ by a rotary evaporator (TE 120 - Tecnal ${ }^{\circledR}$, Piracicaba, $\mathrm{SP}$, Brazil). The nanoparticles were recovered and isolated of the free drug non-encapusulated by centrifugation (19000 rpm, $20^{\circ} \mathrm{C}, 45 \mathrm{~min}$ ) (Z36HK Centrifuge, Hermle ${ }^{\circledR}$ Wehingen, BH, Germany). The precipitate was freezedried (dispersed in cryoprotectant sucrose 15\%,w/v) and stored for posterior use.

Mean diameter and polydispersity index (PDI) were analyzed by photon correlation spectroscopy using a Dynamic Light Scattering Brookhaven 90 Plus (Brookhaven ${ }^{\circledR}$, Blue Point Road Holtsville, NY, United States), at $25^{\circ} \mathrm{C}$, in $90^{\circ}$ scattering angle and wavelength of $659 \mathrm{~nm}$. The determination of the amount of FA encapsulated into nanoparticles was performed indirectly. The supernatant obtained after ultracentrifugation of the nanoparticle dispersion, which contained the free drug, was diluted in acetonitrile $(1: 100 \mathrm{v} / \mathrm{v})$, filtered on membrane pore $0.22 \mu \mathrm{m}$ and analyzed by HPLC using methodology previously validated. The encapsulation efficiency (EE\%) was obtained from Eq. 4 and expressed as mean EE\% and $\mathrm{SD}$. Analyses were performed in triplicate.

$$
E E \%=100 \times \frac{(\text { Initial FA }- \text { Free FA })}{\text { Initial FA }} \quad \text { Equation } 4
$$

where Initial FA represents the amount of FA added to the formulation of nanoparticles and free FA represents the amount of free drug not incorporated into the nanoparticles, quantified by HPLC in the supernatant.

\section{RESULTS AND DISCUSSION}

\section{Method development}

British Pharmacopoeia provides a method for quantifying FA by HPLC, but its elution is by gradient, using phosphoric acid and acetonitrile (British Pharmacopoeia Commission, 2011). An isocratic elution methodology presents greater simplicity of execution, low cost and reduced time. Literature describes solvents, such as acetonitrile, methanol, acetic acid, orthophosphoric acid, acetate buffer solution and ultrapure water for FA determination in plants, plasma and some lipid particles (Carbone et al., 2014; Li et al., 2008; Li, et al., 2004; Li, Bi, 2003; Lu et al., 2005; Seo et al., 2011; Trombino et al., 2013; Wang et al., 2015). Based on literature, initially it was tested several proportions of acetonitrile and $0.5 \%$ glacial acetic acid as mobile phase using a flow rate of $0.8 \mathrm{~mL} / \mathrm{min}$. With low proportions of acetonitrile (less than $20 \%$ ), irregular and tailing peaks were obtained, therefore, the proportion of the mobile phase was changed to increase the amount of acetonitrile. The best peak, in relation to its symmetry and width was found using a flow rate of 1.0 $\mathrm{mL} / \mathrm{min}$ and a mobile phase composed of acetonitrile: $0.5 \%$ acetic acid $(37: 63 \mathrm{v} / \mathrm{v})$. In these conditions, FA was detected in round to $4.5 \mathrm{~min}$ (Figure 1), a time that allows a large number of analyzes in a short time and with low cost with reagents.

The system suitability of this method was evaluated based on the number of theoretical plates, peak symmetry (described by the tailing factor) and retention factor during the run of FA standard solution over five repetitions. The results presented in Table I and chromatographic parameters are in accordance with the criteria established by the US FDA (1994).

TABLE I - System suitability of the HPLC method ( $\mathrm{n}=5$ )

\begin{tabular}{lcc}
\hline $\begin{array}{l}\text { Chromatographic } \\
\text { parameter }\end{array}$ & Result & $\begin{array}{c}\text { Acceptance } \\
\text { criteria }\end{array}$ \\
\hline $\begin{array}{l}\text { Number of theorical } \\
\text { plates (N) }\end{array}$ & $3211.07 \pm 29.88$ & $\mathrm{~N}>2000$ \\
Tailing factor (T) & $1.09 \pm 0.02$ & $\mathrm{~T} \leq 2$ \\
Retention factor $(\mathrm{k})$ & $2.15 \pm 0.00$ & $\mathrm{k}>2$ \\
\hline
\end{tabular}

\section{Method validation}

\section{Linearity and range}

Linearity indicates the ability of a method to demonstrate the results obtained are directly proportional to the concentration of analyte existing in the sample (ICH, 2005). In the present study, linearity was analyzed based on the construction of a calibration curve with six different concentrations between 10 and $100 \mu \mathrm{g} / \mathrm{mL}$ and by calculating the regression and correlation coefficient equation (r) by the method of least squares.

An (r) of 0.999 was obtained, evidencing the linearity of the method in this range. Additionally, the calculated line equation, $y=54629.2405( \pm 932.5326) \mathrm{x}$ +48094.7369 ( \pm 24960.6400$)$, was used in subsequent assays for quantification of the standard and sample solutions. The validity of the test was confirmed by ANOVA, which showed the significance of the regression and that the deviation from linearity was not significant $(\mathrm{p}<0.0001)$. 


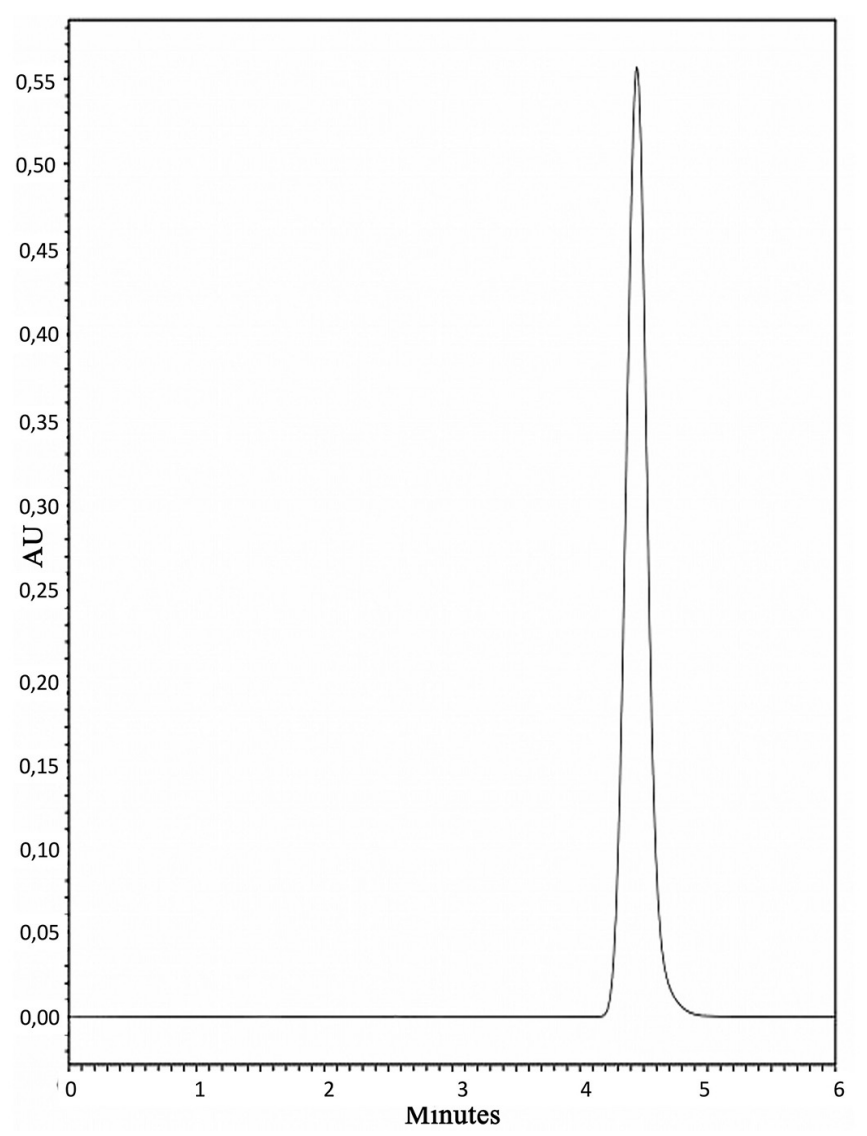

FIGURE 1 - Representative chromatogram of $100 \mu \mathrm{g} / \mathrm{mL}$ FA standard solution. Mobile phase: acetonitrile: $0.5 \%$ acetic acid $(37: 63 \mathrm{v} / \mathrm{v})$, flow rate: $1.0 \mathrm{~mL} / \mathrm{min}, \lambda: 320 \mathrm{~nm}$.

\section{$\angle O D$ and $L O Q$}

LOD is the lowest amount of analyte, which can be detected in a sample, but not necessarily quantified. LOQ demonstrates the lowest amount of analyte determined with acceptable accuracy and precision (ICH, 2005). For these analyses, a specific calibration curve with concentrations below the expected range was constructed and analyzed by linear regression. From the SD of the intercept with the y-axis and the curve slope, LOD and LOQ were calculated.

The (r) found was 0.99917 , thus meeting recommendations ( $\mathrm{r}$ of at least 0.99 ) and confirming the linearity of the method ( $\mathrm{p}<0.0001$ - ANOVA). From line equation, $\mathrm{y}=55890.4530( \pm 796.0461) \mathrm{x}-7244.7629$ $( \pm 1730.6330)$, it was possible to calculate the LOD $(102.18 \mathrm{ng} / \mathrm{mL})$ and LOQ (309.65 ng/mL).

\section{Precision: repeatability and intermediate precision}

FA sample solutions in low, medium and high concentrations $(10,50$, and $100 \mu \mathrm{g} / \mathrm{mL})$ were prepared in quintuplicate and analyzed on the same day (intra-day analysis) or on three different days (inter-day analysis) to demonstrate the precision at level of repeatability and intermediate precision, respectively. According to AOAC (2016), to be considered a precise method, the RSD should not exceed $5.3 \%$ for solutions of $100 \mu \mathrm{g} / \mathrm{mL}$ and $7.3 \%$ at concentrations of 10 and $50 \mu \mathrm{g} / \mathrm{mL}$. In this assay, there were obtained RSD below the recommended limit, being the highest value of $3.15 \%$ (Table II). Therefore, the precision of the method was confirmed.

TABLE II - Precision assay: repeatability and intermediate precision $(\mathrm{n}=5)$

\begin{tabular}{|c|c|c|c|}
\hline $\begin{array}{l}\text { FA sample } \\
\text { solution } \\
(\mu \mathrm{g} / \mathrm{mL})\end{array}$ & $\begin{array}{c}\text { Quantified } \\
\text { concentration } \\
\pm \mathrm{SD}(\mu \mathrm{g} / \mathrm{mL})\end{array}$ & $\begin{array}{c}\text { Recovery } \pm \text { SD } \\
\text { (\%) }\end{array}$ & RSD (\%) \\
\hline \multicolumn{4}{|c|}{ Repeatability } \\
\hline 10 & $9.74 \pm 0.31$ & $97.40 \pm 3.07$ & 3.15 \\
\hline 50 & $49.30 \pm 0.88$ & $98.60 \pm 1.76$ & 1.79 \\
\hline 100 & $101.60 \pm 1.34$ & $101.609 \pm 1.34$ & 1.32 \\
\hline \multicolumn{4}{|c|}{ Intermediate precision } \\
\hline \multicolumn{4}{|c|}{ Day 1} \\
\hline 10 & $9.74 \pm 0.31$ & $97.40 \pm 3.07$ & 3.15 \\
\hline 50 & $49.30 \pm 0.88$ & $98.60 \pm 1.76$ & 1.79 \\
\hline 100 & $101.60 \pm 1.34$ & $101.60 \pm 1.34$ & 1.32 \\
\hline \multicolumn{4}{|c|}{ Day 2} \\
\hline 10 & $10.13 \pm 0.12$ & $101.29 \pm 1.25$ & 1.23 \\
\hline 50 & $50.53 \pm 1.40$ & $101.06 \pm 2.79$ & 2.77 \\
\hline 100 & $102.10 \pm 1.25$ & $102.10 \pm 1.25$ & 1.23 \\
\hline \multicolumn{4}{|c|}{ Day 3} \\
\hline 10 & $9.89 \pm 0.27$ & $98.88 \pm 2.67$ & 2.70 \\
\hline 50 & $48.00 \pm 1.05$ & $96.00 \pm 2.09$ & 2.18 \\
\hline 100 & $101.59 \pm 1.18$ & $101.59 \pm 1.18$ & 1.16 \\
\hline
\end{tabular}

FA: Ferulic acid; SD: Standard deviation; RSD: Relative standard deviation

\section{Accuracy}

Accuracy of the method was demonstrated by the percentage of recovery of three different concentrations of FA solutions $(10,50$ and $100 \mu \mathrm{g} / \mathrm{mL})$ spiked in blank nanoparticles. Results are expressed in Table III, indicating the accuracy of the method. According to the AOAC (2016), to be considered an accurate method, the recovery values should be between 90 and $107 \%$ for $100 \mu \mathrm{g} / \mathrm{mL}$ solution and between 80 and $110 \%$ for 50 and $10 \mu \mathrm{g} / \mathrm{mL}$.

Specificity

Specificity of the method was evaluated by comparing chromatograms of potential formulation interferences (supernatant from blank nanoparticles and 
TABLE III - Percent recovery and RSD obtained by the accuracy test $(\mathrm{n}=5)$

\begin{tabular}{lccc}
\hline Standard solution $(\boldsymbol{\mu g} / \mathbf{m L})$ & $\begin{array}{c}\text { Quantified concentration } \pm \mathbf{S D} \\
(\boldsymbol{\mu g} / \mathbf{m L})\end{array}$ & Recovery $\pm \mathbf{S D}(\%)$ & RSD (\%) \\
\hline 10 & $10.13 \pm 0.12$ & $101.29 \pm 1.25$ & 1.23 \\
50 & $50.53 \pm 1.40$ & $101.06 \pm 2.79$ & 2.77 \\
100 & $102.10 \pm 1.25$ & $102.10 \pm 1.25$ & 1.23 \\
\hline
\end{tabular}

SD: Standard deviation; RSD: Relative standard deviation

$0.5 \%$ CS solution) with FA standard solution (Figure 1) and FA sample (Figure 2a).

It can be observed in Figure 2, the FA retention time in round to $4.5 \mathrm{~min}(\mathrm{~A})$, however, in the chromatograms obtained from the supernatant of blank nanoparticles (B) and from the CS solution (C), no peaks were found in the same retention time. The results showed there was no interference at the retention time of FA from the formulation components. In that sense, it is possible to confirm the specificity of the purposed method.

\section{Robustness}

Robustness is the ability of the method to resist on small and deliberate variations of the analytical parameters (ICH, 2005). Table IV shows the results of the quantification of FA, represented as percentage of recovery and RSD, after changes in the flow rate and in the mobile phase. There was no statistical difference in recovery obtained by the reference method and when variations in the proportion of mobile phase were applied $(p>0.05)$, therefore, the method is robust for this change. However, the methodology showed to be sensible to changes in the flow rate, requiring greater caution and attention for small variations in this chromatographic parameter $(\mathrm{p}<0.05)$

\section{Forced degradation studies (stability indicating} property)

In order to verify the specificity of the method as regards the impurities and the degradation products, as well as to promote information about the drug stability,

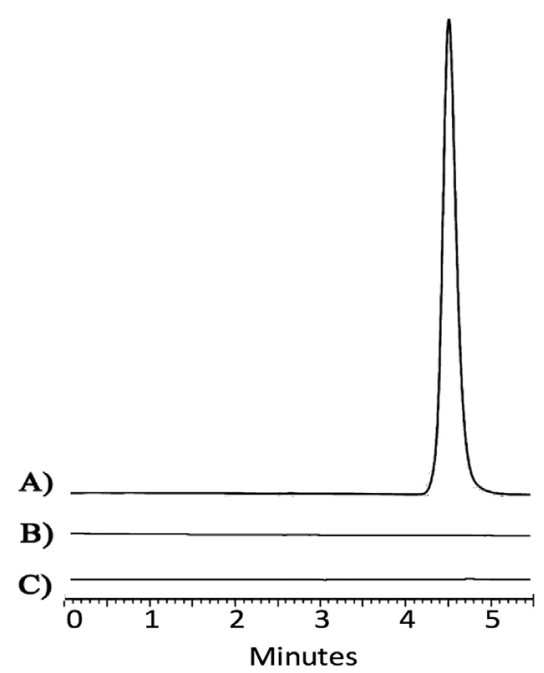

FIGURE 2 - Representative chromatograms of: A) ferulic acid sample solution, B) supernatant from blank PLGA nanoparticles, C) $0.5 \%$ chitosan solution.

a forced degradation study was performed. To evaluate this parameter, FA standard solutions $(50 \mu \mathrm{g} / \mathrm{mL})$ were exposed to basic hydrolysis, acid hydrolysis, oxidation, visible light and temperature of $-20^{\circ} \mathrm{C}$, and subsequently quantified. The chromatograms and percentage of recovery are shown in Figure 3 and Table V, respectively.

The chromatograms of the samples exposed to acid hydrolysis, oxidation, visible light and temperature of -20 ${ }^{\circ} \mathrm{C}$, did not present alteration in FA retention time, allowing its quantification. However, when the FA sample was

TABLE IV - Robustness results at different levels of flow rate and mobile phase proportion $(n=3)$

\begin{tabular}{lccc}
\hline \multirow{2}{*}{ Variation } & \multicolumn{3}{c}{ Recovery $\pm \mathbf{R S D}(\mathbf{\%})$} \\
\cline { 2 - 4 } & $\mathbf{1 0} \mathbf{\mu g} / \mathbf{m L}$ & $\mathbf{5 0} \mathbf{~ g} / \mathbf{m L}$ & $\mathbf{1 0 0} \boldsymbol{\mu g} / \mathbf{m L}$ \\
\hline Reference & $99.32 \pm 4.67^{\mathrm{a}}$ & $98.04 \pm 1.57^{\mathrm{a}}$ & $101.02 \pm 1.41^{\mathrm{a}}$ \\
Flow rate $0.95 \mathrm{~mL} / \mathrm{min}$ & $102.40 \pm 2.93^{\mathrm{b}}$ & $107.25 \pm 1.66^{\mathrm{b}}$ & $109.12 \pm 0.49^{\mathrm{b}}$ \\
Flow rate $1.05 \mathrm{~mL} / \mathrm{min}$ & $91.27 \pm 3.18^{\mathrm{c}}$ & $92.59 \pm 1.48^{\mathrm{c}}$ & $95.57 \pm 0.86^{\mathrm{c}}$ \\
Mobile phase acetonitrile:0.5\% acetic acid; $35: 65 \mathrm{v} / \mathrm{v}$ & $100.29 \pm 1.89^{\mathrm{a}}$ & $102.21 \pm 1.05^{\mathrm{a}}$ & $104.67 \pm 0.99^{\mathrm{a}}$ \\
Mobile phase acetonitrile:0.5\% acetic acid; 39:61 v/v & $99.98 \pm 1.64^{\mathrm{a}}$ & $101.97 \pm 1.97^{\mathrm{a}}$ & $104.49 \pm 0.06^{\mathrm{a}}$ \\
\hline
\end{tabular}

RSD: relative standard deviation; $a, b$, c: Means in a column with different superscripts differ significantly $(\mathrm{p}<0.05)$ by Tukey's test 
exposed to alkaline $\mathrm{pH}$, there was a displacement of the peak, and the retention time was 4 min. Furthermore, the possible degradation product obtained from the alkaline hydrolysis changed the FA characteristic peak shape (Figure $3 b$ ). The chromatogram of the acid degraded sample showed one additional peak with very low intensity at retention time of $2.2 \mathrm{~min}$ (Figure $3 \mathrm{c}$ ). The chromatogram of the FA treated with $\mathrm{H}_{2} \mathrm{O}_{2}$ showed an additional peak at 2.5 min (Figure 3d).

Percentage of recovery (Table V) was adequate for exposure to acid medium, visible light and temperature of $-20^{\circ} \mathrm{C}$ (between $97.49 \pm 0.40$ and $101.52 \pm 0.27$ ), indicating stability in these conditions. For the exposure to oxidation, the recovery was slightly lower, although still in accordance with the AOAC (2016) recommended for the concentration of $50 \mu \mathrm{g} / \mathrm{mL}$ (80 to $110 \%$ ). However, after the exposure to basic medium, due to the displacement and change of the peak shape by possible degradation products, quantification was not possible to be performed.

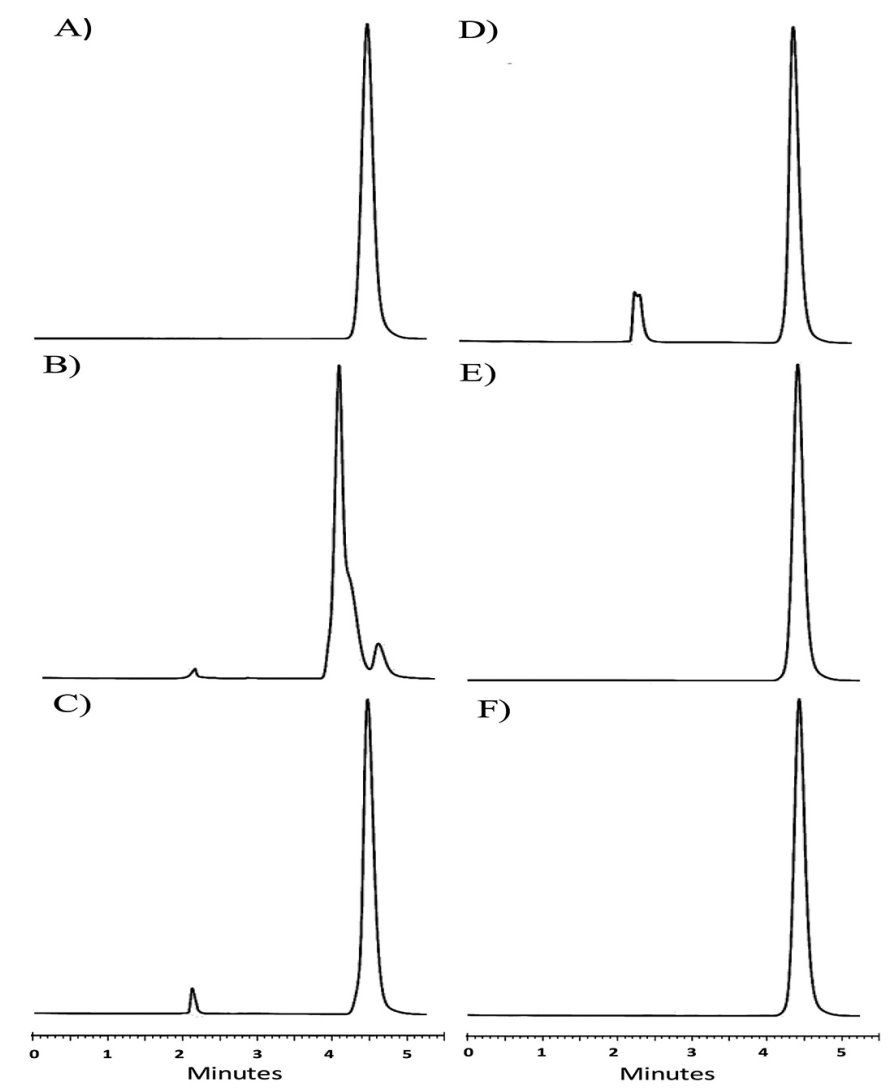

FIGURE 3 - Chromatograms obtained after forced degradation test for $24 \mathrm{~h}$. A) Ferulic acid standard solution - Reference (50 $\mu \mathrm{g} / \mathrm{mL}) \mathrm{B}$ ) After basic hydrolysis ( $\mathrm{NaOH} 1 \mathrm{~mol} / \mathrm{L}) \mathrm{C}$ ) After acid hydrolysis $(\mathrm{HCl} 1 \mathrm{~mol} / \mathrm{L}) \mathrm{D})$ After oxidation $\left.\left(\mathrm{H}_{2} \mathrm{O}_{2} 3 \%\right) \mathrm{E}\right)$ After exposure to visible light $\mathrm{F}$ ) After storage at $-20{ }^{\circ} \mathrm{C}$.
TABLE V - Results of quantification of FA after forced degradation test for $24 \mathrm{~h}(\mathrm{n}=3)$

\begin{tabular}{lcc}
\hline Stress condition & $\begin{array}{c}\text { Quantified } \\
\text { concentration } \pm \text { SD } \\
(\boldsymbol{\mu g} / \mathbf{m L})\end{array}$ & $\begin{array}{c}\text { Recovery } \pm \text { SD } \\
(\%)\end{array}$ \\
\hline Reference & $50.53 \pm 1.40$ & $\mathrm{NA}$ \\
Basic hydrolysis & $\mathrm{NQ}$ & $\mathrm{NQ}$ \\
Acid hydrolysis & $49.26 \pm 0.20$ & $97.49 \pm 0.40$ \\
Oxidation & $46.28 \pm 1.30$ & $91.59 \pm 2.58$ \\
Visible light & $51.30 \pm 0.14$ & $101.52 \pm 0.27$ \\
$-20^{\circ} \mathrm{C}$ & $50.94 \pm 0.82$ & $100.81 \pm 1.63$ \\
\hline
\end{tabular}

SD: Standard deviation; NA: Not applicable; NQ: Not quantified

\section{Method applicability}

PLGA nanoparticles containing FA coated with CS were properly obtained and presented mean size of $234 \pm 15$ $\mathrm{nm}$ and polydispersity index of $0.195 \pm 0.018$, indicating homogenous size distribution. EE\% was assessed by the HPLC method and the results showed about $60 \pm 5 \%$ of FA encapsulated in nanoparticles. Literature shows a similar result for FA encapsulated in PLGA nanoparticles (76\%) (Merlin et al., 2012).

Due to the relative absence of studies in which quantification of FA is carried out in polymeric nanoparticles by HPLC, as well as the lack of validation and further detailing on the chromatographic methods used in other pharmaceuticals products, HPLC-PDA method here validated can be considered an alternative for the quantitative analysis of FA. The method showed to be simple, fast, reliable and it fulfill the requirements to be applied in the encapsulation efficiency of FA in nanoparticles. Also, the method can be employed as a stability indicating one.

\section{CONCLUSIONS}

A simple, efficient and reliable method to quantify FA in PLGA nanoparticles coated with CS by reversedphase HPLC with PDA was developed and adequately validated according to $\mathrm{ICH}$ and AOAC. The reliability of the method has been proven by parameters of linearity, range, LOD, LOQ, precision, accuracy, specificity, robustness and a study of forced degradation. The analytical methodology presented a short retention time, allowing rapid quantification of FA with low quantities of reagents. Also, the method proved to be suitable for evaluating the FA encapsulation efficiency in PLGA-CS nanoparticles. 


\section{ACKNOWLEDGEMENTS}

This study was supported by the CAPES (Coordenação de Aperfeiçoamento de Pessoal de Nível Superior), Fundação Araucária, CNPq (Conselho Nacional de Desenvolvimento Científico Tecnológico), and Finep (Financiadora de Estudos e Projetos).

\section{REFERENCES}

ACEITUNO-MEDINA, M.; MENDOZA, S.; RODRIGUEZ, B.A.; LAGARON, J.M.; LOPEZ-RUBIO, A. Improved antioxidant capacity of quercetin and ferulic acid during in-vitro digestion through encapsulation within food-grade electrospun fibers. J. Funct. Foods, v.12, p.332-341, 2015.

ANDREASEN, M.F.; CHRISTENSEN, L.P.; MEYER, A.S.; HANSEN, Å. Content of phenolic acids and ferulic acid dehydrodimers in 17 rye (secale cereale L.) varieties. $J$. Agric. Food Chem., v.48, n.7, p.2837-2842, 2000.

ANSELMI, C.; CENTINI, M.; RICCI, M.; BUONOCORE, A.; GRANATA, P.; TSUNO, T.; FACINO, R.M. Analytical characterization of a ferulic acid/ $\gamma$-cyclodextrin inclusion complex. J. Pharm. Biomed. Anal., v.40, n.4, p.875-881, 2006.

BARBEROUSSE, H.; ROISEUX, O.; ROBERT, C.; PAQUOT, M.; DEROANNE, C.; BLECKER, C. Analytical methodologies for quantification of ferulic acid and its oligomers. J. Sci. Food Agric., v.88, n.9, p.1494-1511, 2008.

BONDI, M.L.; MONTANA, G.; CRAPARO, E.F.; PICONE, P.; CAPUANO, G.; CARLO, M.D.; GIAMMONA, G. Ferulic acid-loaded lipid nanostructures as drug delivery systems for alzheimer's disease: preparation, characterization and cytotoxicity studies. Curr. Nanosci., v.5, n.1, p.26-32, 2009.

BRITISH PHARMACOPOEIA COMMISSION. British Pharmacopoeia. London: Stationery Office, 2011.

CARBONE, C.; CAMPISI, A.; MUSUMECI, T.; RACITI, G.; BONFANTI, R.; PUGLISI, G. FA-loaded lipid drug delivery systems: preparation, characterization and biological studies. Eur. J. Pharm. Sci., v.52, p.12-20, 2014.

CRAPARO, E.F.; GENNARA, C.; CHIARA, O.M.; GIROLAMO, T.; LUISA, B.M.; GAETANO, G. Amphiphilic poly(hydroxyethylaspartamide) derivativebased micelles as drug delivery systems for ferulic acid. $J$. Drug Target., v.17, n.1, p.78-88, 2009.
DAS NEVES, J.; SARMENTO, B.; AMIJI, M.M.; BAHIA, M.F. Development and validation of a rapid reversed-phase HPLC method for the determination of the non-nucleoside reverse transcriptase inhibitor dapivirine from polymeric nanoparticles. J. Pharm. Biomed. Anal., v.52, n.2, p.167$172,2010$.

DE JONG, W.H.; BORM, P.J.A. Drug delivery and nanoparticles: applications and hazards. Int. J. Nanomed., v.3, n.2, p.133149, 2008.

FOOD AND DRUG ADMINISTRATION. FDA. Reviewer Guidance: validation of chromatographic methods. Silver Spring, 1994. Available at: <http://www.fda.gov/ downloads/Drugs/.../Guidances/UCM134409.pdf>. Accessed on: March 2016.

GUO, T.; SUN, Y.; SUI, Y.; LI, F. Determination of ferulic acid and adenosine in Angelicae Radix by micellar electrokinetic chromatography. Anal. Bioanal. Chem., v.375, n.6, p.840$843,2003$.

GUY, P.A.; RENOUF, M.; BARRON, D.; CAVIN, C.; DIONISI, F.; KOCHHAR, S.; REZZI, S.; WILLIAMSON, G.; STEILING, H. Quantitative analysis of plasma caffeic and ferulic acid equivalents by liquid chromatography tandem mass spectrometry. J. Chromatogr. B, v.877, n.31, p.39653974, 2009.

HINGSE, S.S.; DIGOLE, S.B.; ANNAPURE, U.S. Method development for simultaneous detection of ferulic acid and vanillin using high-performance thin layer chromatography. J. Anal. Sci. Technol., v.5, n.1, p.1-9, 2014.

INTERNATIONAL CONFERENCE ON HARMONIZATION. ICH. Validation of analytical procedures: text and methodology Q2(R1). Geneva: IFPMA, 2005. Available at: <http://www.ich.org/fileadmin/Public Web Site/ ICH_Products/Guidelines/Quality/Q2_R1/Step4/Q2_R1 Guideline.pdf $>$. Accessed on: Aug. 2015.

INTERNATIONAL OFFICIAL METHODS OF ANALYSIS. AOAC. Appendix F: Guidelines for Standard Method Performance Requirements. Rockville, 2016. Available at: $<$ http://www.eoma.aoac.org/app_f.pdf $>$. Accessed on: March 2016 
KAREPARAMBAN, J.; NIKAM, P.; JADHAV, A.; KADAM, V. A validated high-performance liquid chromatograhy method for estimation of ferulic acid in asafoetida and polyherbal preparation. Indian J. Pharm. Sci., v.75, n.4, p.493-495, 2013.

KIM, H.J.; RYU, K.; KANG, J.H.; CHOI, A.J.; KIM, T.I.; $\mathrm{OH}$, J.M. Anticancer activity of ferulic acid-inorganic nanohybrids synthesized via two different hybridization routes, reconstruction and exfoliation-reassembly. Scient. W. J., v.2013, p.1-9, 2013.

LI, F.Q.; SU, H.; WANG, J.; LIU, J.Y.; ZHU, Q.G.; FEI, Y.B.; PAN, Y.H.; HU, J.H. Preparation and characterization of sodium ferulate entrapped bovine serum albumin nanoparticles for liver targeting. Int. J. Pharm., v.349, n.12, p.274-282, 2008

LI, X.; LI, X.; WANG, L.; LI, Y.; XU, Y.; XUE, M. Simultaneous determination of danshensu, ferulic acid, cryptotanshinone and tanshinone IIA in rabbit plasma by HPLC and their pharmacokinetic application in danxiongfang. J. Pharm. Biomed. Anal., v.44, n.5, p.1106-1112, 2007.

LI, X.P.; YU, J.; LUO, J.Y.; LI, H.S.; HAN, F.J.; CHEN, X.G.; HU, Z.D. Simultaneous determination of chlorogenic acid, caffeic acid, ferulic acid, protocatechuic acid and protocatechuic aldehyde in Chinese herbal preparation by RP-HPLC. Chem. Pharm. Bull. (Tokyo), v.52, n.10, p.12511254, 2004.

LI, Y.; BI, K. HPLC determination of ferulic acid in rat plasma after oral administration of Rhizoma Chuanxiong and its compound preparation. Biomed. Chromatogr., v.17, n.8, p.543-546, 2003.

LIMA, D.L.D.; DUARTE, A.C.; ESTEVES, V.I. Optimization of phenolic compounds analysis by capillary electrophoresis. Talanta, v.72, n.4, p.1404-1409, 2007.

LIMA, E.; FLORES, J.; CRUZ, A.S.; LEYVA-GOMEZ, G.; KROTZSCH, E. Controlled release of ferulic acid from a hybrid hydrotalcite and its application as an antioxidant for human fibroblasts. Micropor. Mesopor. Mat., v. 181, p. $1-7,2013$

LU, G.H.; CHAN, K.; LEUNG, K.; CHAN, C.L.; ZHAO, Z.Z.; JIANG, Z.H. Assay of free ferulic acid and total ferulic acid for quality assessment of Angelica sinensis. J. Chromatogr. $A$, v.1068, n.2, p.209-219, 2005.
MABINYA, L.V.; MAFUNGA, T.; BRAND, J.M. Determination of ferulic acid and related compounds by thin layer chromatography. Afr. J. Biotechnol., v.5, n.13, p.1271-1273, 2006.

MERLIN, J.P.J.; RAJENDRA PRASAD, N.; SHIBLI, S.M.A.; SEBEELA, M. Ferulic acid loaded Poly-d,1-lactide-coglycolide nanoparticles: systematic study of particle size, drug encapsulation efficiency and anticancer effect in nonsmall cell lung carcinoma cell line in vitro. Biomed. Prev. Nutr., v.2, n.1, p.69-76, 2012.

NADAL, J.M.; TOLEDO, M.G.; PUPO, Y.M.; PADILHA DE PAULA, J.; FARAGO, P.V.; ZANIN, S.M. A stabilityindicating hplc-dad method for determination of ferulic acid into microparticles: development, validation, forced degradation, and encapsulation efficiency. J. Anal. Methods Chem., v.2015, ArticleID286812, 10p., 2015.

OLTHOF, M.R.; HOLLMAN, P.C.H.; BUIJSMAN, M.N.C.P.; VAN AMELSVOORT, J.M.M.; KATAN, M.B. Chlorogenic acid, quercetin-3-rutinoside and black tea phenols are extensively metabolized in humans. J. Nutr., v.133, n.6, p.1806-1814, 2003.

PICONE, P.; BONDI, M.L.; MONTANA, G.; BRUNO, A.; PITARRESI, G.; GIAMMONA, G.; DI CARLO, M. Ferulic acid inhibits oxidative stress and cell death induced by $\mathrm{Ab}$ oligomers: improved delivery by solid lipid nanoparticles. Free Radic. Res., v.43, n.11, p.1133-1145, 2009.

QI, J.; JIN, X.; HUANG, L.; PING, Q. Simultaneous determination of hydroxysafflor yellow A and ferulic acid in rat plasma after oral administration of the co-extractum of Rhizoma chuanxiong and Flos Carthami by HPLC-diode array detector. Biomed. Chromatogr., v.21, n.8, p.816-822, 2007.

RONDINI, L.; PEYRAT-MAILLARD, M.-N.; MARSSETBAGLIERI, A.; FROMENTIN, G.; DURAND, P.; TOMÉ, D.; PROST, M.; BERSET, C. Bound ferulic acid from bran is more bioavailable than the free compound in rat. J. Agric. Food Chem., v.52, n.13, p.4338-4343, 2004.

SAIKIA, J.P.; KONWARH, R.; KONWAR, B.K.; KARAK, $\mathrm{N}$. Isolation and immobilization of Aroid polyphenol on magnetic nanoparticles: Enhancement of potency on surface immobilization. Colloids Surf. B Biointerf., v.102, p.450456, 2013. 
SEN, A.; MILLER, S.S.; ARNASON, J.T.; FULCHER, R.G. Quantitative determination by high performance liquid chromatography and microspectro-fluorimetry of phenolic acids in maize grain. Phytochem. Anal., v.2, n.5, p.225-229, 1991.

SEO, Y.C.; CHOI, W.Y.; LEE, C.G.; CHA, S.W.; KIM, Y.O.; KIM, J.C.; DRUMMEN, G.P.; LEE, H.Y. Enhanced immunomodulatory activity of gelatin-encapsulated Rubus coreanus Miquel nanoparticles. Int. J. Mol. Sci., v.12, n.12, p.9031-9056, 2011.

SHEN, G.; JIA, X.; JIN, J.; PANG, L.; CHEN, Z.; DU, B. Determination of ferulic acid by flow injection chemiluminescence analysis based on enhancement of the N-bromobutanimide-eosin-CrCl3 system in alkaline solution. Luminescence, v.28, n.4, p.536-541, 2013.

SRIVASTAVA, S.; SINGH, A.P.; SINGH RAWAT, A.K. A HPTLC method for the identification of ferulic acid from Lycopodium clavatum. Asian Pac. J. Trop. Biomed., v.2, n.1, Supplement, p.S12-S14, 2012.

TEE-NGAM, P.; NUNANT, N.; RATTANARAT, P.; SIANGPROH, W.; CHAILAPAKUL, O. Simple and rapid determination of ferulic acid levels in food and cosmetic samples using paper-based platforms. Sensors, v.13, n.10, p.13039-13053, 2013.

TROMBINO, S.; CASSANO, R.; FERRARELLI, T.; BARONE, E.; PICCI, N.; MANCUSO, C. Trans-ferulic acid-based solid lipid nanoparticles and their antioxidant effect in rat brain microsomes. Colloids Surf. B Biointerf., v.109, p.273-279, 2013.

VICHAPONG, J.; SOOKSERM, M.; SRIJESDARUK, V.; SWATSITANG, P.; SRIJARANAI, S. High performance liquid chromatographic analysis of phenolic compounds and their antioxidant activities in rice varieties. Lwt-Food Sci. Technol., v.43, n.9, p.1325-1330, 2010.

VILIAN, A.T.E.; CHEN, S.-M. Preparation of carbon nanotubes decorated with manganese dioxide nanoparticles for electrochemical determination of ferulic acid. Mikrochim. Acta, v.182, n.5, p.1103-1111, 2014.
WALDRON, K.W.; PARR, A.J.; NG, A.; RALPH, J. Cell wall esterified phenolic dimers: identification and quantification by reverse phase high performance liquid chromatography and diode array detection. Phytochem. Anal., v.7, n.6, p.305-312, 1996.

WANG, J.; CAO, Y.; SUN, B.; WANG, C.Characterisation of inclusion complex of trans-ferulic acid and hydroxypropylß-cyclodextrin. Food Chem., v.124, n.3, p.1069-1075, 2011.

WANG, W.; GUO, J.; ZHANG, J.; PENG, J.; LIU, T.; XIN, Z. Isolation, identification and antioxidant activity of bound phenolic compounds present in rice bran. Food Chem., v.171, p.40-49, 2015.

WANG, X.Y.; MA, X.H.; LI, W.; CHU, Y.; GUO, J.H.; LI, S.M.; WANG, J.M.; ZHANG, H.C.; ZHOU, S.P.; ZHU, Y.H. Simultaneous determination of five phenolic components and paeoniflorin in rat plasma by liquid chromatographytandem mass spectrometry and pharmacokinetic study after oral administration of Cerebralcare granule ${ }^{\circledR}$. J. Pharm. Biomed. Anal., v.86, p.82-91, 2013.

WU, W.; LEE, S.Y.; WU, X.; TYLER, J.Y.; WANG, H.; OUYANG, Z.; PARK, K.; XU, X.M.; CHENG, J.X. Neuroprotective ferulic acid (FA)-glycol chitosan (GC) nanoparticles for functional restoration of traumatically injured spinal cord. Biomaterials, v.35, n.7, p.2355-2364, 2014.

YANG, M.-L.; SONG, Y.-M. Synthesis and investigation of water-soluble anticoagulant warfarin/ferulic acid grafted rare earth oxide nanoparticle materials. $R S C A d v$., v.5, n.23, p.17824-17833, 2015.

ZHANG, T.; YANG, X.; ZHANG, P.; ZHU, M.; HE, Z.; BI, $\mathrm{K}$. Determination of ferulic acid in rat plasma by liquid chromatography-tandem mass spectrometry method: application to a pharmacokinetic study. Anal. Lett., v.42, n.14, p.2157-2169, 2009.

ZHOU, Y.; HUA, S.; YU, J.H.; DONG, P.; LIU, F.J.; HUA, D.B. A strategy for effective radioprotection by chitosan-based long-circulating nanocarriers. J. Mater. Chem. B, v.3, n.15, p.2931-2934, 2015.

Received for publication on $16^{\text {th }}$ July 2016 Accepted for publication on $17^{\text {th }}$ January 2017 